УДК 371.26:910.1:004.054

Геращенко Альона Павлівна

вчитель географії та інформатики

Турбівська ЗОШ І-ІІ ст. ім. Г. І. Петровського, смт. Попільня, Житомирська область, Україна

a.p.g@mail.ru

\title{
ВИКОРИСТАННЯ ІКТ НА УРОКАХ ГЕОГРАФІЇ НА ПРИКЛАДІ ТЕСТОВИХ ПРОГРАМ ДЛЯ ПЕРЕВІРКИ ЗНАНЬ УЧНІВ
}

\begin{abstract}
Анотація. У статті зібрано і проаналізовано матеріали про комп’ютерні тестові програми, такі як Assistent, MyTestX, easyQuizzy, Айрен, Майстер-Тест та інші, які можуть бути використані педагогами під час вивчення шкільного курсу «Географія» для модернізації сучасного педагогічного процесу. Аналіз можливостей комп'ютерних тестових програм показав, що вони можуть бути застосовані на уроках географії як для поточної перевірки знань учнів загальноосвітніх навчальних закладів, так і для тематичної перевірки, а також для підготовки учнів до державної підсумкової атестації і зовнішнього незалежного оцінювання.
\end{abstract}

Ключові слова: комп'ютерні тестові програми; онлайн-тести; географія; інформаційнокомунікаційні технології навчання.

\section{1. ВСТУП}

Постановка проблеми. Пошук прогресивних, оптимальних, ефективних інформаційно-комунікаційних технологій навчання учнів на уроках географії засобами комп'ютерних тестів і необхідність пошуку інноваційних форм і методів навчання під час вивчення шкільного курсу «Географія» визначає актуальність дослідження обраної теми. Одним із завдань повсякденної вчительської праці $є$ необхідність здійснювати контроль знань учнів. Форми контролю, що застосовуються вчителями, дуже різноманітні, але найчастіше використовуються письмове або усне опитування. На жаль, ці форми мають певні недоліки. Під час проведення усного опитування - це відносно велика витрата часу уроку і неможливість виставити велику кількість оцінок, а під час проведення письмових робіт кількість оцінок зростає, але багато часу йде на перевірку. Тому все більшої популярності набувають комп'ютерні тести.

Аналіз останніх досліджень і публікацій. Одне 3 головних завдань освіти в умовах величезного інформаційного потоку полягає в тому, щоб навчити учнів ефективно використовувати інформаційно-комунікаційні технології (ІКТ). Швидкий розвиток ІКТ дає нові можливості в освіті, висуваючи, натомість, нові вимоги до навчання.

Аналізуючи, для яких видів роботи на уроках географії найчастіше застосовують IКТ педагоги, як українські (Шульгіна О. В. [17], Новенко Д. В. [7], Юхимович О. [18]), так і зарубіжні (Мартишкова М. А. [16]), виділимо основні з них - це використання мережі Інтернет; підготовка до олімпіади, ЗНО; розробка презентацій, проектів, сайтів; робота 3 електронними книгами й атласами; виконання практичних робіт; створення електронної газети; демонстрація схем, слайдів, географічних об'єктів, карт, фотографій, графіків, діаграм; для контролю знань у вигляді комп'ютерних тестів. На останньому виді контролю знань учнів зупинимось детальніше.

Тестування як ефективний спосіб перевірки знань знаходить у школі все більше застосування. Однією з основних і безперечних його переваг є мінімум часових витрат на отримання надійних підсумків контролю. Під час тестування використовують як бланкові, так і електронні варіанти. Останні особливо привабливі, тому що дозволяють отримати результати практично відразу після завершення тесту. 
Дослідженнями ефективних способів перевірки знань як традиційних, так і за допомогою комп'ютера в різний час займалось багато педагогів, науковців (Ільїнський А. М. [4], Новенко Д. В. [8], Шульгина О. В. [17], Юхимович О. [18]). Зокрема, у працях Салей Т. В. [13] розглянуто використання відкритих (перспективних) тестів на уроках географії. Сідоренко О. М. [14] описав основні можливості програми для тестування easyQuizzy.

Тестування в педагогіці виконує три основні взаємопов'язані функції: діагностичну, навчальну і виховну.

Діагностична функція полягає у виявленні рівня знань, умінь, навичок учня. Це основна і найочевидніша функція тестування. За об'єктивності, широти і швидкості діагностування, тестування перевершує всі інші форми педагогічного контролю.

Навчальна функція тестування полягає в мотивуванні учня до активізації роботи iз засвоєння навчального матеріалу. Для посилення навчальної функції тестування можуть бути використані додаткові заходи стимулювання учнів, такі як роздача переліку запитань для самостійної підготовки, наявність в самому тесті навідних запитань і підказок, спільний розбір результатів тесту.

Виховна функція проявляється в періодичності i неминучості тестового контролю. Це дисциплінує, організовує і направляє діяльність учнів, допомагає виявити й усунути прогалини в знаннях, формує прагнення розвинути свої здібності.

Тестування - більш справедливий метод. Воно ставить всіх учнів у рівні умови, як у процесі контролю, так і в процесі оцінювання, практично виключаючи суб'єктивізм викладача.

Відомо, що саме тестування є основною формою складання іспитів - ЗНО. Тому потрібно обов'язково вводити тестові технології в систему навчання.

Метою статті $є$ дослідження можливостей тестових програм під час вивчення шкільного курсу «Географія» для підвищення якості шкільної географічної освіти.

\section{2. РЕЗУЛЬТАТИ ДОСЛІДЖЕННЯ}

Останнім часом усе більшого застосування знаходить тестування за допомогою комп'ютерних тестових програм. Тестові завдання можуть складатися з використанням різноманітних комп'ютерних інструментів, починаючи від різних редакторів і програм для розробки презентацій і до використання мов програмування і можливостей мережі Інтернет. варіантах.

Роботу з тестовими програмами у ході уроку технічно можна організувати у двох

Перший: учні можуть працювати в режимі on-line, тобто з безпосереднім доступом до Інтернету. Цей варіант рекомендується у тих випадках, коли у навчальному закладі $є$ достатня кількість комп'ютерів 3 досить швидким доступом до Інтернету і завантаження навчальних матеріалів не займає багато часу. Однак, і в цьому випадку вчитель має попередньо перевірити доступність необхідних Інтернет-ресурсів, оскільки сервери і сайти можуть бути тимчасово недоступні з різних технічних причин.

Другий варіант більш надійний — це виконання завдань у тестовій програмі, що встановлена на ПК.

Комп’ютерні тестові програми, такі як Assistent, MyTestX, easyQuizzy, Айрен, Майстер-Тест та онлайн-тести, можуть бути успішно використані під час вивчення шкільного курсу «Географія» та підготовки учнів до ЗНО, олімпіади чи різноманітних конкурсів. Аналіз цих програм проводився виключно серед безкоштовних та умовно безкоштовних програм. 


\subsection{Assistent}

Assistent - програма, що дозволяє створювати тести, а також повноцінні навчальні програми на основі взаємодії з програмою PowerPoint. Програма зайняла 1 місце за підсумками проведеного корпорацією Microsoft конкурсу Microsoft Office Extensions [1].

Assistent призначена, як для розробки комп'ютерних тестів, так і для розробки навчальних програм на основі PowerPoint 3 пакету Microsoft Office. Основною перевагою $\epsilon$ те, що цю програму можна використовувати на уроці географії і як тестуючу програму для перевірки знань, і як навчальну програму. Також вона має невеликі програмні вимоги: операційна система Microsoft Windows 9x 3 підтримкою російської мови, RAM 16 Мб, 6 Мб простору на жорсткому диску.

У програмі Assistent $\epsilon$ можливість створювати 7 типів різних завдань, чотирибальна або 100 бальна шкала оцінювання, а також уточнення оцінки засобами класичної математичної статистики, є можливість задати критерії оцінювання, використати малюнки для ілюстрації завдання і як варіанти відповідей, використати мультимедійні засоби. Також дана програма веде облік різної складності завдань, за потреби задається довільний порядок виконання завдань.

Дуже зручно користуватись такою функцією, як накопичувальний статистичний аналіз за відповідями на кожне конкретне питання для уточнення оцінок учнів.

До переваг використання даної програми можна віднести роботу на окремому комп'ютері чи в локальній мережі, особливо для сільських шкіл. Тести створюються легко - шляхом перетворення документа Microsoft Word. Результат тесту i використовуваних файлів зберігається шляхом перетворення в документ Microsoft Word, архів WinRar, або ж друкується.

Зручна програма й тим, що має можливість заборони на перемикання між вікнами під час тестування учнів, $є$ аналіз впливу випадкового вгадування і велика кількість (до 12) варіантів відповіді.

Програма функціональна без реєстрації. Для навчальних закладів реєстрація є безкоштовною.

\subsection{MyTestX}

MyTestX - це система програм (програма тестування учнів, редактор тестів $\mathrm{i}$ журнал результатів) для створення і проведення комп'ютерного тестування, збору та аналізу результатів, виставлення оцінки за вказаною в тесті шкалою [6].

Програма працює під OC Windows XP, Vista, 7, 8. Для роботи під Linux можна використовувати Wine.

Програма легка і зручна у використанні. Працює з 10 типами завдань: одиночний вибір, множинний вибір, встановлення порядку проходження, встановлення відповідності, вказівка істинності чи хибності тверджень, ручне введення числа, ручне введення тексту, вибір місця на зображенні, перестановка букв, заповнення пропусків. У тесті можна використовувати будь-яку кількість різних типів завдань. У завданнях із вибором відповіді (одиночний, множинний вибір, вказівка порядку, вказівка істинності) можна використовувати до 10 варіантів відповіді, на відміну від програми Assistent (там 12 варіантів).

Програма складається з трьох модулів.

1. Модуль тестування (MyTestStudent).

2. Редактор тестів (MyTestEditor).

3. Журнал тестування (MyTestServer). 
Використовуючи різні режими і параметри тестування, можна ефективно розв’язувати різноманітні завдання як для навчання, так і для перевірки знань.

Оскільки MyTestX має дуже зручний редактор тестів із дружнім інтерфейсом, будь-який учитель-географ, який володіє комп'ютером навіть на початковому рівні, може легко скласти власні тести і використовувати їх на уроках. Параметри тестування, завдання, звуки і зображення до завдань для кожного окремого тесту - усе зберігається в одному файлі тесту. У тесті можна використовувати як завдання одного типу, так і завдання різних типів. Кількість груп і завдань у тесті не обмежена. Запитання з варіантами відповіді можуть включати до десяти варіантів. Для кожного завдання задається до п'яти формулювань запитання. Текст запитання і варіантів відповіді (там, де вони можливі) підтримують форматування тексту, вставки малюнків, таблиць, символів, фрагментів карт, що особливо цінне для географів.

Під час складання тестів учитель може відзначити, які саме завдання 3 тесту будуть задані учневі, скільки виділити часу на обдумування, чи буде показана правильна відповідь, чи будуть збережені або відправлені результати тестування та багато інших опцій, що легко можна налаштувати за допомогою редактора тестів. У програмі $є$ багато способів форматування тексту запитань i варіантів відповіді, наприклад - визначити шрифт, колір символів і фону, розбивати текст на абзаци i застосовувати до них розширене форматування, використовувати списки, вставляти малюнки і формули. До кожного завдання можна задати складність (кількість балів за правильну відповідь), прикріпити підказку (показ може бути за штрафні бали) і пояснення правильної відповіді (виводиться в разі помилки в навчальному режимі).

Особливістю цієї програми є можливість використовувати не тільки кілька варіантів запитання завдання, але й зручно створювати вибірку завдань для учнів, перемішувати завдання і варіанти відповідей. Це значно зменшує списування учнів під час проходження одного і того ж тесту.

До переваг використання цієї програми відносимо те, що тестування можна організувати як локальне, так і мережеве. Піж час мережевого тестування результати можуть бути автоматично передані мережею в модуль Журнал, а можуть бути відправлені електронною поштою, або на веб-сервер в Інтернет методом POST.

Ще однією перевагою програми MyTestX $€$ використання будь-якої системи оцінювання. Система оцінювання і iї налаштування можна задати або змінити в редакторі тесту.

За наявності комп'ютерної мережі можна, використовуючи модуль журналу MyTestX, легко:

- організувати централізований збір й обробку результатів тестування результати виконання завдань виводяться учню і відправляються вчителеві. Учитель може оцінити або проаналізувати їх в будь-який зручний для нього час;

- організувати роздачу тестів учням через мережу - зникає необхідність щоразу копіювати файли тестів на всі комп'ютери. Роздавати можна відразу кілька різних тестів;

- безпосередньо стежити за процесом тестування. Учитель може спостерігати, хто і який тест виконує, скільки завдань вже виконано і яка їх результативність.

Програма підтримує декілька незалежних один від одного режимів: навчальний, штрафний, вільний i монопольний. У навчальному режимі учневі виводяться повідомлення про його помилки, може бути показано пояснення до завдання. У штрафному режимі за неправильні відповіді в тестованого віднімаються бали, наразі можна пропустити завдання (бали не додаються і не віднімаються). У вільному режимі учень може відповідати на запитання в будь-якій послідовності, переходити 
(повертатися) до будь-якого запитання самостійно. У монопольному режимі вікно програми займає весь екран і його неможливо згорнути.

Учитель географії у разі правильного відбору контрольного матеріалу, змісту тесту може використати його не тільки для контролю знань учнів, але й для навчання. Отже, дозволяючи учневі самостійно виявляти прогалини у своїх знаннях і вживати заходи для їх усунення. У таких випадках можна говорити про значний навчальний потенціал тестових завдань, використання яких $\epsilon$ ефективним напрямом практичної реалізації принципу єдності і взаємозв'язку навчання і контролю.

Кожен тест має оптимальний час тестування, зменшення або перевищення якого знижує якісні показники тесту. Тому в настройках тесту, передбачено обмеження часу виконання, як усього тесту, так і будь-якої відповіді на завдання (для різних завдань можна виставити різний час).

MyTestX має високу ступінь захисту, як тестових завдань, так і результатів. Завдяки тому, що для тесту можна задати кілька різних паролів (для відкриття, редагування, тестування), відредагувати тест особам, що не мають на це право, стає практично неможливо. Результати тестування зберігаються в захищений файл, який неможливо відредагувати. Тому оцінки учнів завжди об'єктивні і не залежать від лояльності вчителя чи інших факторів. 3 огляду на те, що результати тестування можуть зберігатися як на учнівському ПК, так і на вчительському, ймовірність втрати результатів зводиться до $0 \%$. Програма продемонструвала високу надійність роботи в школах.

Важливо, що програма MyTestX постійно розвивається, враховуючи потреби багатьох користувачів, і наразі нікого не ущемляючи. Додаються нові функції для тестування, але не переобтяжується зміст і структура постійно використовуваних.

До багатьох корисних функцій, які $є$ в програмі для проведення комп'ютерного тестування, можна ще додати те, що, якщо учень з якихось причин не може виконувати тест за ПК (наприклад, за станом здоров'я), то дуже легко і швидко можна сформувати бланковий варіант тесту.

Програма MyTestX доступна у двох версіях.

1. Простій - некомерційне використання програми не вимагає грошових виплат. Будь-яка освітня установа, учитель і учень можуть безкоштовно використовувати програму на основі ліцензійної угоди.

2. Розширеній (MyTestXPro) - більш функціональній версії. MyTestXPro $\epsilon$ умовно-безкоштовною програмою і поширюється за принципом "спробуй перед тим, як купити".

\section{3. Айрен}

Айрен - це безкоштовна програма, що дозволяє створювати тести для перевірки знань і проводити тестування в локальній мережі, через Інтернет або на одиночних комп'ютерах. Вона невелика за обсягом (до 5,7 Мб), підтримується OC Windows XP, Vista, 7 [11].

Айрен складається 3 двох частин — мережевої версії і програми для редагування.

Мережева версія використовується, як для створення тестів, так і для проведення тестування по мережі й обробки результатів. Під час тестування вчитель спостерігає на своєму комп'ютері за докладними відомостями про успіхи кожного з учнів. Після закінчення роботи ці дані зберігаються в архіві, де їх надалі можна переглядати й аналізувати за допомогою вбудованих в програму засобів.

Тести, як і в інших подібних програмах, можуть включати в себе завдання різних типів: закритого (з вибором однієї або декількох відповідей), відкритого (з уведенням 
відповіді 3 клавіатури), на встановлення відповідності, на впорядкування та на класифікацію.

Редактор тестів Айрен застосовується для створення власне тестів. Підготовлені тести можна згодом використовувати в мережевій версії або, зберігши їх у вигляді автономних виконуваних (.Ехе) файлів, роздати учням для самостійної роботи.

Попри це, передбачено створення тестів у вигляді автономних виконуваних файлів, які можна роздати учням для проходження тестування без використання мережі i без збереження результатів. Такий режим орієнтований, насамперед, на тести, призначені для самоперевірки. Учневі, щоб приступити до тестування, досить запустити отриманий файл на будь-якому комп'ютері без його попередньої інсталяції.

\subsection{EasyQuizzy}

EasyQuizzy - безкоштовна програма, у якій можна створювати тести на українській мові, використовувати в текстах малюнки, діаграми та схеми.

Тести easyQuizzy зручно використовувати на уроках під час щоденних швидких опитувань і підготовки до ЗНО [5].

Основні характеристики програми:

- створений текст зберігається в одному файлі, який не потребує інсталяції на іншому ПК під час його редагування;

- передбачені підказки, що вказують на кількість можливих відповідей до окремо взятого запитання;

- $\quad \epsilon$ можливість фіксування часу проходження тесту;

- створюється протокол тесту, який можна роздрукувати;

- автоматично створюються службові відомості: дата, час проходження тесту, загальна, опрацьована і правильна кількість запитань, відсоткове співвідношення правильних відповідей до загальної кількості;

- $\epsilon$ можливість збереження протоколу тестування до окремого файлу 3 розширенням rtf;

- програма easyQuizzy підтримує конвертування тестів, створених в інших програмах, як, наприклад, testW, з можливістю їх редагувати, доповнювати та зберігати.

Також важливою функцією даної програми є захист тест-файлів парольним доступом на їх завантаження і редагування [12].

\section{5. Онлайн-тести}

Останнім часом все більшої популярності серед учнів набирають онлайн-тести на різноманітних Інтернет-сервісах, за допомогою яких можна підготуватись до певної теми $з$ географії чи до державної підсумкової атестації [16; 9; 12]. Наприклад, такі електронні ресурси, як ЗНО-2014 (http://zno-ua.net/lesson/geography) та багато подібних йому, де використовуються тестові завдання Українського центру оцінювання якості освіти. Більшість 3 них орієнтована на підготовку до зовнішнього незалежного оцінювання учнів. На жаль, на думку автора, якість цих ресурсів бажає бути кращою. Зокрема наявність реклами, що розміщена на сайтах, відволікає учнів, і на уроці їх недоцільно використовувати.

Проте, є освітній сервіс, що не містить інформації, яка буде відволікати учнів від проходження тесту. Майстер-Тест — це безкоштовний Інтернет-сервіс, що дозволяє вчителеві географії створювати онлайн-тести самостійно, проводити інтерактивне тестування учнів. За відсутності доступу до Інтернету готовий тест можна скачати i виконати його на ПК, і для цього не потрібно встановлювати на комп'ютер додаткові 
програми. На даний час сервіс Майстер-Тест не продовжує розроблятися у зв'язку з відсутністю фінансування [2].

\section{3. ВИСНОВКИ ТА ПЕРСПЕКТИВИ ПОДАЛЬШИХ ДОСЛІДЖЕНЬ}

Проаналізувавши дані тестові комп'ютерні програми, підсумуємо, що їх використання на уроках географії можливе на будь-якому етапі уроку: засвоєння, закріплення знань і вмінь учнів, на підсумкових уроках, для підготовки учнів до державної підсумкової атестації, зовнішнього незалежного оцінювання. Кожна 3 досліджуваних тестових комп'ютерних програм має багато функцій, серед яких для учителя географії важливими будуть:

- функції з вибору тестових завдань різного типу, можливість додавати фрагменти карт, чи будь-яких інших картинок як в умову тесту (у всіх досліджуваних програмах), так і у відповідь (у програмах Assistent, MyTestX);

- можливість працювати як у мережі, так і на окремих ПК;

- можливість сформувати бланковий варіант тесту (наприклад у програмі MyTestX);

- створення тестів шляхом перетворення документа Microsoft Word;

- захист тестів парольним доступом та ін.

Отже, застосування комп'ютерних тестів на уроках географії може мати позитивні наслідки, тому що реалізується особистісно-орієнтований підхід до навчання, формуються вміння учнів обирати головне, аналізувати, розвиваються навички комп'ютерної грамотності. Результативність процесу навчання багато в чому залежить від ретельності розробки методики контролю знань.

У разі правильного підбору контрольного матеріалу зміст тесту може бути використано не тільки для контролю знань учнів, але й для навчання. Тому учень самостійно може виявляти прогалини у своїх знаннях і вживати заходів для їх усунення. У таких випадках можна говорити про значний навчальний потенціал тестових завдань, використання яких $є$ ефективним напрямом практичної реалізації принципу єдності і взаємозв'язку навчання і контролю. Застосування комп'ютерних тестів як однієї з форм фронтальної перевірки знань і вмінь учнів, дозволяє задіяти всіх учнів, наразі економиться час на уроці, розв'язується проблема накопичення оцінок, підвищується інтерес до предмета. Попри це, систематичне застосування подібної перевірки привчає учнів бути активними і сумлінно готуватися до уроків.

Перспективою подальших досліджень $є$ детальне вивчення й опис переваг i недоліків даних тестових комп'ютерних програм, виявлення і розробка нових програм для розвитку творчого потенціалу учнів на уроках географії і модернізація сучасного географічного процесу навчання 3 метою формування знань, умінь і навичок учня, необхідних для реалізації себе в сучасному суспільстві.

\section{СПИСОК ВИКОРИСТАНИХ ДЖЕРЕЛ}

1. Assistent - создание контролирующих и обучающих компьютерных програм [Електронний pecypc] / О. Г. Деменченок. — Режим доступу : http://asksystem.narod.ru.

2. Безкоштовне створення освітніх онлайн тестів і проведення тестування [Електронний ресурс] / Сервіс онлайн тестування Майстер-Тест - 2013. - Режим доступу : http://master-test.net/uk.

3. Биков В. Ю. Методологічні та методичні основи створення і використовування електронних засобів навчального призначення / В. Ю. Биков, В. В. Лапінський. // Комп’ютер у школі та сім’ї. - 2012. 一№ 2 - C. 3-7.

4. Ільїнський А. М. Використання інформаційних технологій на уроках географії / А. М. Ільїнський // Географія. - 2004. — № 23. - С. 15-16. 
5. Конструктор тестов easyQuizzy [Електронний ресурс] / Проект Шкуропия А., Полсакова И. // NetCrate Software. - 2014. - Режим доступу : http://easyquizzy.ru.

6. Компьютерное тестирование знаний MyTestX [Електронний ресурс] / А. С. Башлаков. — 2014. — Режим доступу : http://mytest.klyaksa.net.

7. Мартышкова М. А. Электронный контроль знаний на уроках географии [Електронний ресурс] / М. А. Мартышкова Фестиваль педагогических идей «Открытый урок». - М. : Издательский дом «Первое сентября», 2011. — Режим доступу : http://festival.1september.ru/articles/587481.

8. Новенко Д. В. Новые информационные технологии в обучении / Д. В. Новенко // География в школе. - 2004. - № 5. - С. 47-51.

9. Онлайн тест $3 \mathrm{HO} \mathrm{з} \mathrm{географії} \mathrm{[Електронний} \mathrm{ресурс]} \mathrm{/} \mathrm{Неофициальный} \mathrm{студенческий} \mathrm{сайт} \mathrm{о} \mathrm{высшем}$ образовании и студенческой жизни. - $2014 . \quad$ - Режим доступу : http://studportal.net.ua/page.php?al=zno_po_geografii_onlajn.

10. Підготовка, тестування ЗНО [Електронний ресурс] / Test ZNO - 2013. - Режим доступу : http://testzno.com.ua/?Itemid=2\&option=com_jquarks\&view=quiz.

11. Програма тестирования знаний - Айрен [Електронний ресурс] / С. Останин — 2010. — Режим доступу : http://www.irenproject.ru/index.

12. Сайт для підготовки до ЗНО [Електронний ресурс] / Клименко В. - Режим доступу : http://znoua.net/lesson/geography.

13. Салей Т. В. Використання відкритих (перспективних) тестів на уроках географії, як один із шляхів реалізації державних вимог до рівня загальноосвітньої підготовки учнів / Т. В. Салей // Відкритий урок: розробки, технології, досвід. - 2011. - №7/8. -С. 36-37.

14. Сідоренко О. М. Програма для тестування еasyQuizzy / O. М. Сідоренко // Комп'ютер у школі та сім’ї.-2010. - № 5. - С. 17-18.

15. Розпорядження Кабінету Міністрів України від 27 серпня 2010 р. № 1720-р "Про схвалення Концепції Державної цільової соціальної програми підвищення якості шкільної природничоматематичної освіти на період до 2015 року" [Електронний ресурс]. — Режим доступу : http://www.kmu.gov.ua/kmu/control/uk/cardnpd.

16. Український центр оцінювання якості освіти / УЦОЯО (неофіційний) [Електронний ресурс]. 2013. - Режим доступу : http://ukrainetest.com.ua/test.php?model=geography.

17. Шульгина О. В. Возможности и проблемы использования компьютерных технологий в преподавании географии / О. В. Шульгина // География в школе. - 2003. — № 8. - С. 45-49.

18. Юхимович О. Використання комп'ютерної техніки під час вивчення географії / О. Юхимович // Географія та основи економіки в школі. — 2003. — № 5. - С. 16-20.

Матеріал надійшов до редакиії 18.03 .2014 p.

\title{
ИСПОЛЬЗОВАНИЕ ИКТ НА УРОКАХ ГЕОГРАФИИ НА ПРИМЕРЕ ТЕСТОВЫХ ПРОГРАММ ДЛЯ ПРОВЕРКИ ЗНАНИЙ УЧЕНИКОВ
}

\author{
Геращенко Алена Павловна \\ учитель географии и информатики \\ Турбовская ООШ I-II ст. им. Г. И. Петровского, пгт. Попельня, Житомирская область, Украина \\ a.p.g@mail.ru
}

\begin{abstract}
Аннотация. В статье собраны и проанализированы материалы о компьютерных тестовых программах, таких как Assistent, MyTestX, easyQuizzy, Айрен Мастер-Тест и других, которые могут быть использованы педагогами при изучении школьного курса «География» для модернизации современного педагогического процесса. Анализ возможностей компьютерных тестовых программ показал, что они могут быть применены на уроках географии как для текущей проверки знаний учащихся в общеобразовательных учебных заведениях, так и для тематической проверки, а также для подготовки учащихся к государственной итоговой аттестации и внешнего независимого оценивания.
\end{abstract}

Ключевые слова: компьютерные тестовые программы; онлайн-тесты; география; информационно-коммуникационные технологии обучения.

\section{THE USE OF ICT IN GEOGRAPHY LESSONS ON EXAMPLE OF THE TESTING PROGRAMS FOR STUDENTS' KNOWLEDGE EXAMINING}




\title{
Olena P. Herashchenko
}

teacher of geography and informatics

Turbivka G.I. Petrovsky Secondary School I-II deg Popilnya, Zhytomyr region, Ukraine

a.p.g@mail.ru

\begin{abstract}
The material gathered and analyzed in the paper is on the computer testing programs such as Assistent, MyTestX, easy Quizzy, Ayren, Master Test and others that may be used by teachers during the study of school course of "Geography" for the modernization of the modern educational process. The analysis of the possibilities of computer testing programs has showed that they can be applied on the geography lessons both for the current testing of student's knowledge, and for the content checking and for preparation of the students for the state final attestation and external independent assessment.
\end{abstract}

Keywords: computer testing programs; online tests; geography; information and communication technology; training.

\section{REFERENCES (TRANSLATED AND TRANSLITERATED)}

1. Assistent - creation of control and tutoring computer programs [online ] / O. G Demenchenok. Available from: http://asksystem.narod.ru (in Russian).

2. Bykov V. Y. Methodological and methodical basis for the creation and use of electronic media for educational purposes / V. U Bykov, V. V Lapinskyi // The computer in the school and the family. 2012. - № 2 - C. 3-7 (in Ukrainian).

3. Cabinet of Ministers of Ukraine on August 27, 2010 № 1720 "On Approval of the Concept of the National Programme improving the quality of school Natural Sciences and Mathematics Education until 2015" [online]. - Available from : http://www.kmu.gov.ua/kmu/control/uk/cardnpd (in Ukrainian).

4. Computer testyrovanye known MyTestX [online] / A. Bashlakov. - 2014. — Available from : http://mytest.klyaksa.net (in Russian).

5. Design of test easyQuizzy [online] / Project Shkuropyya A., Polsakova I. // NetCrate Software. — 2014. - Available from : http://easyquizzy.ru (in Russian).

6. Free create online educational tests and testing [online] / Online Testing Service Master-Tes. — 2013. Available from : http://master-test.net/uk (in Ukrainian).

7. Iliinskyi A. Use of information technology in geography class // Geography. — 2004. — № 23. — P. 1516 (in Ukrainian).

8. Martyshkova M. A. Electronic control knowledge in geography class [online] / M. A. Martyshkova Festival pedagogical ideas "Open lesson." — Moscow : Publishing House "The first of September." 2011. - Available from : http://festival.1september.ru/articles/587481 (in Russian).

9. NEE -line test of geography [online] / Studencheskyy unofficial site about High society Education and studencheskoy life. - - $\quad 2014 . \quad-\quad$ Available from http://studportal.net.ua/page.php?al=zno_po_geografii_onlajn (in Ukrainian).

10. Novenko D. V. New Projects Information Technology in Education / D. V. Novenko // Geography in school. - 2004. - № 5. - P. 47-51 (in Ukrainian).

11. Preparation, testing NEE [online] / Test ZNO. - 2013. - Available from : http://testzno.com.ua/?Itemid=2\&option=com_jquarks\&view=quiz (in Ukrainian).

12. Program testyrovanyya knowledge - Ayren [online] / S. Ostanyn. - 2010. - Available from : http://www.irenproject.ru/index (in Russian).

13. Sale T. Using open ( advanced ) tests for geography lessons as a way to implement state requirements for the general education students / Forum pedagogical ideas "Lesson" // Open class : design , technology, experience. — 2011. — № 7/8. -P. 36-37 (in Ukrainian).

14. Shulgyna A. Using Possibility and Problems of computer technology in prepodavanyy geography / A. Shulgyna // Geography in school. — 2003. — № 8. - P. 45-49 (in Russian).

15. Sidorenko A. Program for testing easyQuizzy / A. Sidorenko / / Computer for School and Family. 2010. - № 5. - P. 17-18 (in Ukrainian).

16. The site in preparation for the EIT [online] / V. Klimenko. - Available from : http://znoua.net/lesson/geography (in Ukrainian).

17. Ukrainian Center for Educational Quality Assessment / UCEQA (unofficial ) [online]. — 2013. Available from : http://ukrainetest.com.ua/test.php?model=geography (in Ukrainian).

18. Yukhymovych O. The Use of computer technology in the study of geography / O. Yukhymovych // Geography and economic fundamentals in school. — 2003. — № 5. - P. 16-20. 